\title{
Das Triadisches Ballett reloaded: l'opera di Schlemmer al servizio di nuove connessioni spaziali e didattiche
}

\author{
Andrea Marraffa
}

Abstract

A cento anni dalla nascita del Bauhaus, il Balletto Triadico continua ad affascinare e a fare scuola. I gesti, le danze, le geometrie, le forme, partorite dal genio visionario e poliedrico di Oskar Schlemmer appaiono, oggi più che mai, attuali e innovative. In un connubio sinestetico di colori, suoni, odori, emozioni, il balletto è sinonimo di laboratorio didattico, multi-sensoriale e multi-disciplinare. Tutto questo fa parte di una grande macchina-scenica teatrale, propria di una complessa cultura materiale, in grado di connettere l'apollineo e il dionisiaco, il colore e la luce, il disegno e la musica, l'uomo e l'architettura. La ricerca si propone di raccontare le attività di un laboratorio didattico realizzato nell'ambito del corso di Scienze della Formazione Primaria e svolto presso l'Università 'Mediterranea' di Reggio Calabria, dal titolo Das Triadisches Ballett reloaded 3.0. II progetto ha l'obiettivo di 'ricaricare' l'opera teatrale di Schlemmer, valorizzandola attraverso le moderne tecniche di disseminazione e di comunicazione del $\mathrm{CH}$. II Balletto Triadico riprende vita grazie a manichini sartoriali, vestiti di creta, adornati di forme pure e dipinti con colori primari. L'anelito alla vita della Super-Marionetta schlemmeriana, permette di inventare nuovi balletti digitali, ottenuti tramite la tecnica dello Stop-Motion, della Realtà Virtuale e del Motion Tracking. L'ultima parte della Ricerca è orientata alla individuazione di strategie innovative per la accessibilità e la disseminazione del Balletto per le categorie, cosiddette,'con esigenze speciali', in particolare i disabili visivi e gli ipovedenti. Mappe tattili, stampe 3D, litofanie e sinestesie multi-sensoriali sono gli strumenti privilegiati di 'lettura dinamica' delle coreografie, al fine di rendere la loro fruizione universale, democratica e inclusiva.

Parole chiave

Bauhaus, balletto-triadico, stop-motion, didattica, accessibilità.
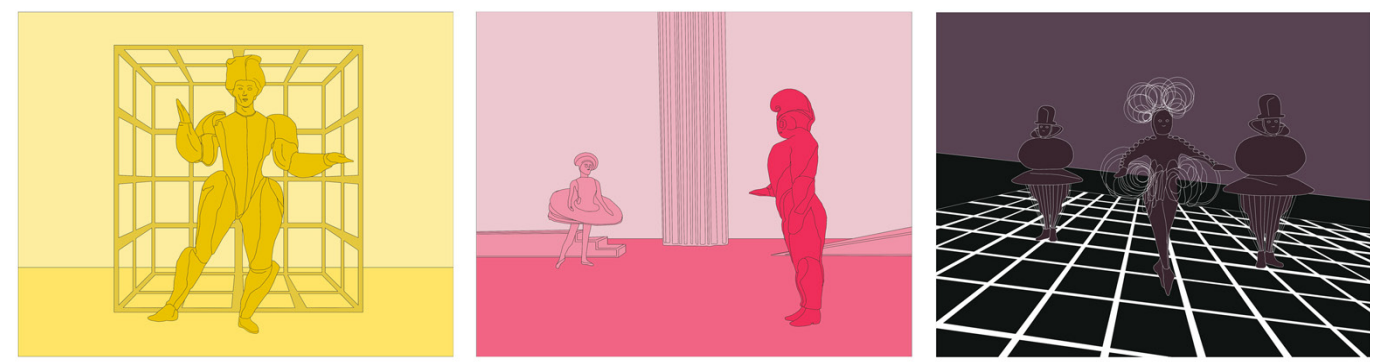


\section{Oskar Schlemmer e il teatro del Bauhaus}

La poetica artistica del teatro del Bauhaus rappresenta ancora oggi un argomento attuale e di notevole interesse per le sue forte implicazioni in ambito artistico, didattico e pedagogico. Nella scuola del Bauhaus, Oskar Schlemmer fu pittore proto-cubista, scultore, maestro artigiano di intagli, regista, coreografo, scenografo, e molto altro. La sua poliedrica personalità artistica contribuì alla creazione di un tipo di arte nuova, totale, multi-disciplinare che vide propria nella danza, e in particolare nel balletto moderno, l'elemento espressivo più alto e più importante: la via preferenziale per raccontare lo spazio, l'architettura, l'uomo.

L'idea di teatro di Schlemmer, dal respiro totale [I] e riformistico, proprio dell'ideologia artistica che si dispiegava nel quadro della Repubblica di Weimar, si fondava su una scuola della costruzione, orientata alla incessante sperimentazione didattica e alla contaminazione tra generi. Per Schlemmer, direttore della Bauhaus-buhne dal 1923 al 1929, il balletto era sintesi di musica, geometria, teatro e danza. Le forme e i colori primari, permettevano l'esaltazione della figura umana, proiettando sulla scena metafisiche visioni, oniriche certezze e inesorabili tentativi di riscatto dell'umanità nei confronti della crescente spinta alla meccanizzazione del XX secolo. Schlemmer guardava alla scenografia e ai drammi cromatici e astratti di Kandinsky, rubandone la forza espressiva e incisiva dei colori; si lasciava ispirare dalle utopiche spinte di meccanizzazione totale di Moholy-Nagy; riusciva a condensare nella marionetta Kleistana tutta una serie di attributi di un ritrovato antropocentrico artistico.

Come un moderno homo faber, Schlemmer aveva un rapporto diretto e concreto con la materia da plasmare. Nei suoi primi disegni e sculture, apparivano evidenti quegli elementi formali puri derivati dal costruttivismo russo, ma anche quelle figure prive di volto dei pittori proto-cubisti e cubisti analitici, (Picasso su tutti), e ancora, i continui giochi cromatici dei tardo impressionisti, in particolare di Holzel, e per ultimo ma non per importanza, l'influenza dell'arte metafisica di De Chirico, in cui la figura umana non era più soltanto una maschera vuota o uno scheletro ligneo, ma tornava a essere il fine ultimo dell'arte totale. Una continua scientificità della ricerca, quella di Schlemmer, protesa alla conquista di una teorizzazione educativa e didattica della forma teatrale perfetta, basata sull'esaltazione della coscienza e della conoscenza della forza dei suoi mezzi artistici più elementari - la linea, la forma e il colore - attraverso la loro distribuzione nello spazio e in continuo rapporto con le figure umane. Lo stile schlemmeriano è espressione di connessioni sinestetiche tra colori, suoni, linee, geometrie, movimenti, emozioni. Un'evoluzione artistica che si condensa e si concretizza in quello che è da sempre considerato come il suo capolavoro: il Balletto Triadico (fig. I).

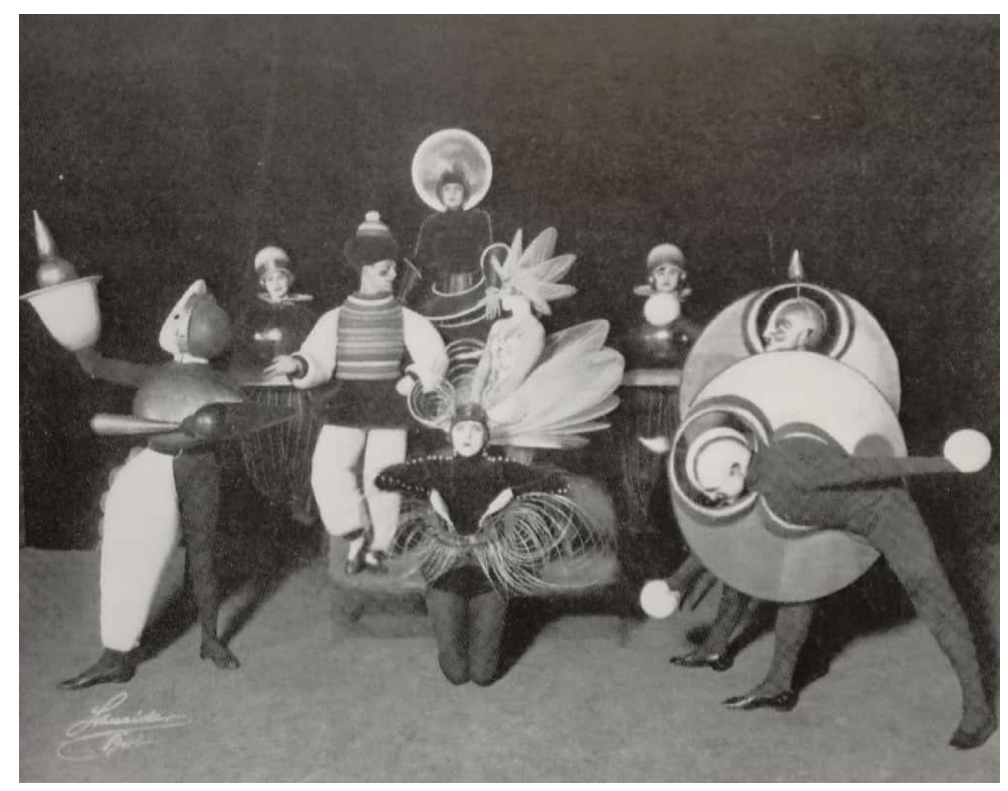




\section{Balletto Triadico: connessioni tra spazio e luce, suono e colore, uomo e architettura}

II Balletto Triadico, in tedesco Das Triadisches Ballett (fig. I), è unanimemente considerato come il capolavoro della poetica schlemmeriana. Frutto di continue sperimentazioni laboratoriali, il balletto è l'emblema della ricerca didattica e multidisciplinare del teatro del Bauhaus. Schlemmer intende il balletto come forma d'arte suprema e totale, la sola degna erede delle antiche forme teatrali greche. II balletto è la danza della triade, scambio dell'Uno, Due eTre: la figura umana in forma, colore, movimento e suono. Per Schlemmer il tre appare come il numero cabalistico per eccellenza, metafora del superamento dell'egocentrismo, dell'annichilamento del contrasto delle dualità e principio della collaborazione collettiva attoriale. II Balletto Triadico è connessione numerica pura [2]: le coreografie di cui esso si compone, in triplo accordo e secondo una successione multipla e magica di numeri primi ( I-5-7, ecc.), mettono in scena diciotto costumi allinterno di dodici sub-stanze (fig. 2), alternando, uno o tre danzatori per volta. Gli attori sono figure disumanizzate, androgine, spesso mascherate, le quali volteggiano sinuosamente con i loro movimenti meccanici, compiendo e completando geometriche coreografie. Tre sono le macro-stanze, asettiche e arredate con pochi elementi architettonici, prolungamenti degli arti umani. Tre sono anche i colori principali delle stanze: giallo, rosa e nero, a cui corrispondono altrettante composizioni musicali, rispettivamente di carattere comico-burlesco (stanza gialla), cerimonioso-solenne (stanza rosa), magico-metafisico-fantastico (stanza nera).

Nelle diverse stanze, i danzatori adornati da costumi molto simili ad armature posticce e goffe, compiono una vera e propria geometrizzazione gestuale totale. Le figure umane sono idealizzate, quasi sovra-individuali, dotate di atteggiamenti espressivi stilizzati e ridotti all'osso [3]. Simili ai manichini geometrici di Seurat, i ballerini di Schllemmer sono disposti sulla scena "come pedine su una scacchiera, con un ritmo di intervalli calcolato quasi matematicamente, in una composizione costruita sulle orizzontali e sulle verticali" [Argan ....anno, pp....]. L'uomo, misura di ogni cosa, è proiezione geometrica dello spazio che ha intorno (fig. 3). I danzatori, quasi sempre visti in posizione frontale, di profilo o di spalle, sono ingabbiati all'interno dei loro costumi-armatura. Simili a vere e proprie architetture in movimento, essi astraggono
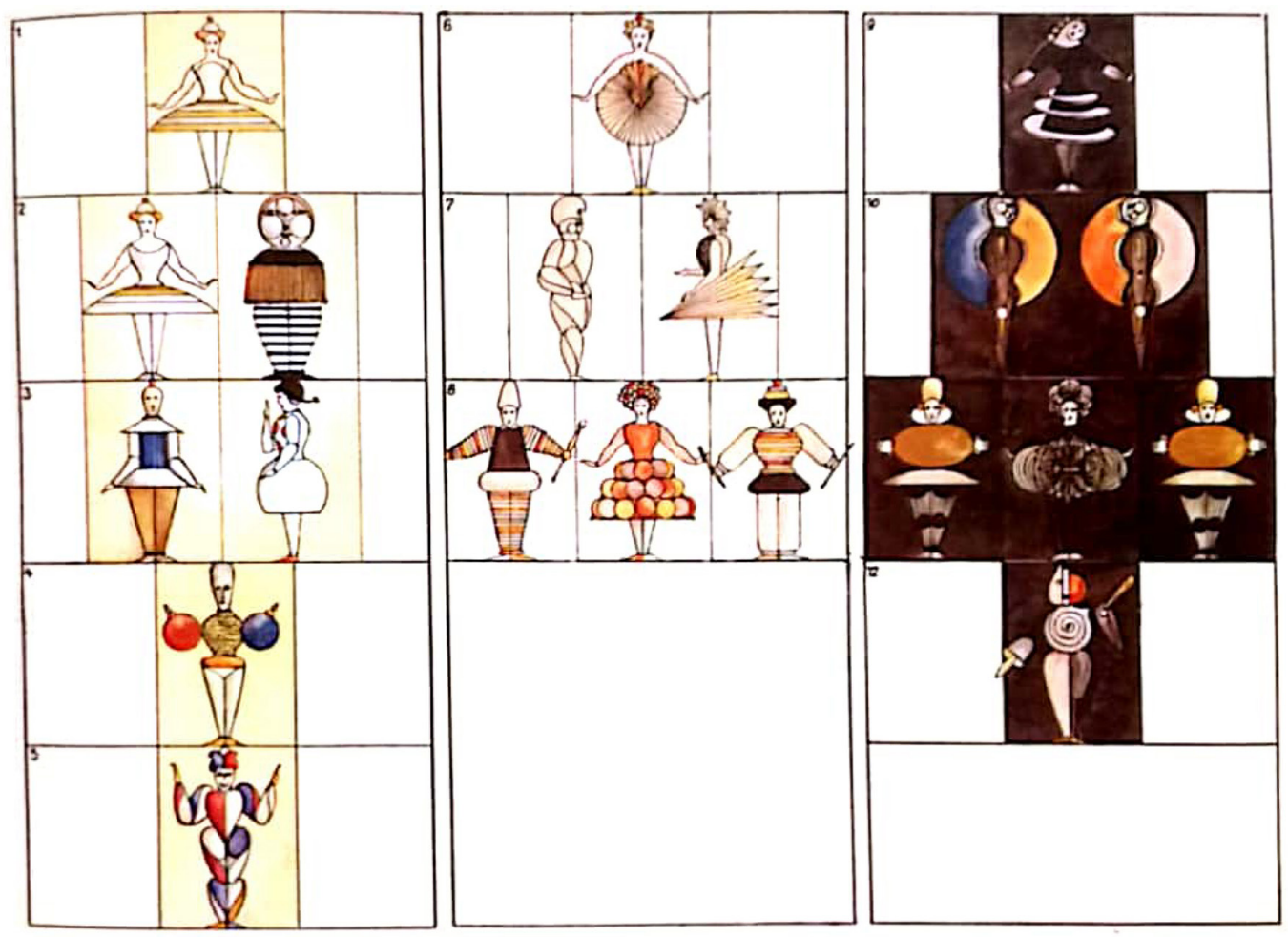

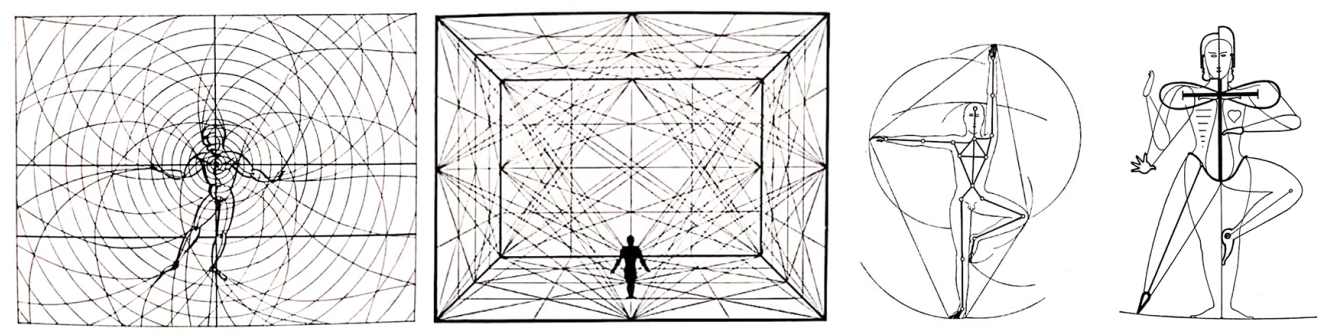

\section{Balletto triadico 3.0 Reloaded: alla ricerca di nuove connessioni didattiche}

La ricerca, qui di seguito presentata, racconta l'esperienza di un laboratorio didattico e multidisciplinare, realizzato nell'ambito del corso di Disegno e comunicazione visiva [4], dal titolo Das Triadische Ballett Reloaded. Teatro, danza e architettura in stop-motion svolto presso I'Università Mediterranea di Reggio Calabria, nel dicembre 2019.

II progetto è stato pensato per rispondere alle esigenze di tre diverse tipologie di pubblico: I) gli studenti del Corso di SdFP; 2) un pubblico generico, fruitore e destinatario dell'offerta culturale e museale; 3 ) il pubblico con 'bisogni speciali', in particolare gli ipovedenti e i disabili visivi.

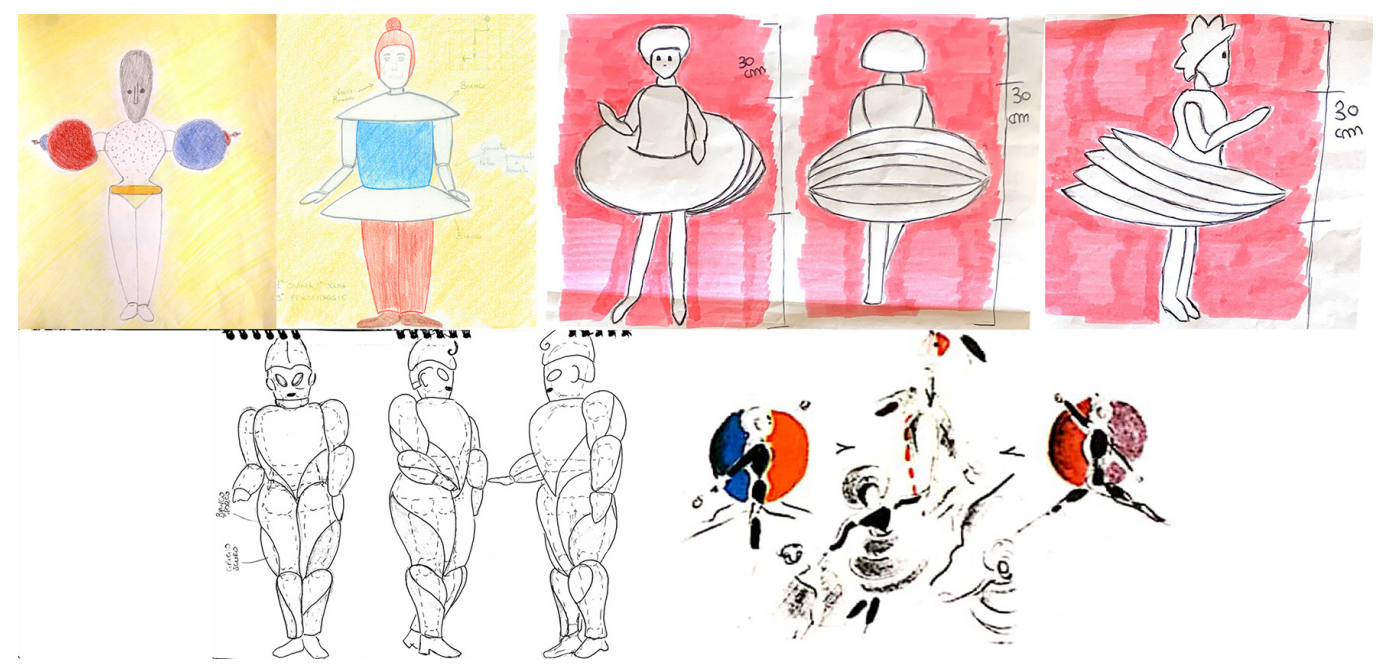


Il laboratorio didattico, i manichini e il Balletto Triadico 3.0

In virtuale connessione didattica, il primo target di pubblico individuato dal progetto, è doppio: da una parte è rappresentato dai potenziali futuri maestri, attuali studenti del corso di laurea in Scienze della Formazione Primaria; dall'altra, invece, dai bambini delle scuole elementari, anch'essi destinatari dell'offerta pedagogica. Una volta presentato il tema del laboratorio, a ciascun studente è stato assegnato un danzatore del balletto di Schlemmer, al fine di ricrearne le fattezze e i movimenti.

A partire da precisi studi preliminari, gli studenti hanno iniziato a dialogare con gli strumenti propri del disegno analogico: sezioni, orto-piani, prospettive, ecc. Gli 'eidotipi anatomici' (fig. 4) dei danzatori androgini schlemmeriani, sono stati la base per la creazione di un vero e proprio modello plastico.

Sui manichini sartoriali in legno sono stati ricreati i goffi e posticci costumi-armatura di Schlemmer, realizzati in creta bianca, stoffa, carta-pesta e, in seguito, colorati con vivaci colori primari a tempera (fig. 5). Come già detto, l'obiettivo principale del progetto è 'ricaricare' e valorizzare l'opera di Schlemmer, attraverso le moderne tecniche di disseminazione e di comunicazione del $\mathrm{CH}$, pur preservando, al tempo stesso, una forte componente artigianale. È quella che Richard Sennett indicava come le qualità dell'homo laborans potenziate dalla tecnica dell'homo faber [Sennett 2008]. Una volta realizzati i diciotto modelli, sono state costruite le scenografie delle tre macro-stanze, in ordine di apparizione, rispettivamente di colore giallo, rosa e nero.

Fig. 5. Realizzazione dei personaggi schlemmerian a parte degli studenti folienze della formazione primaria.

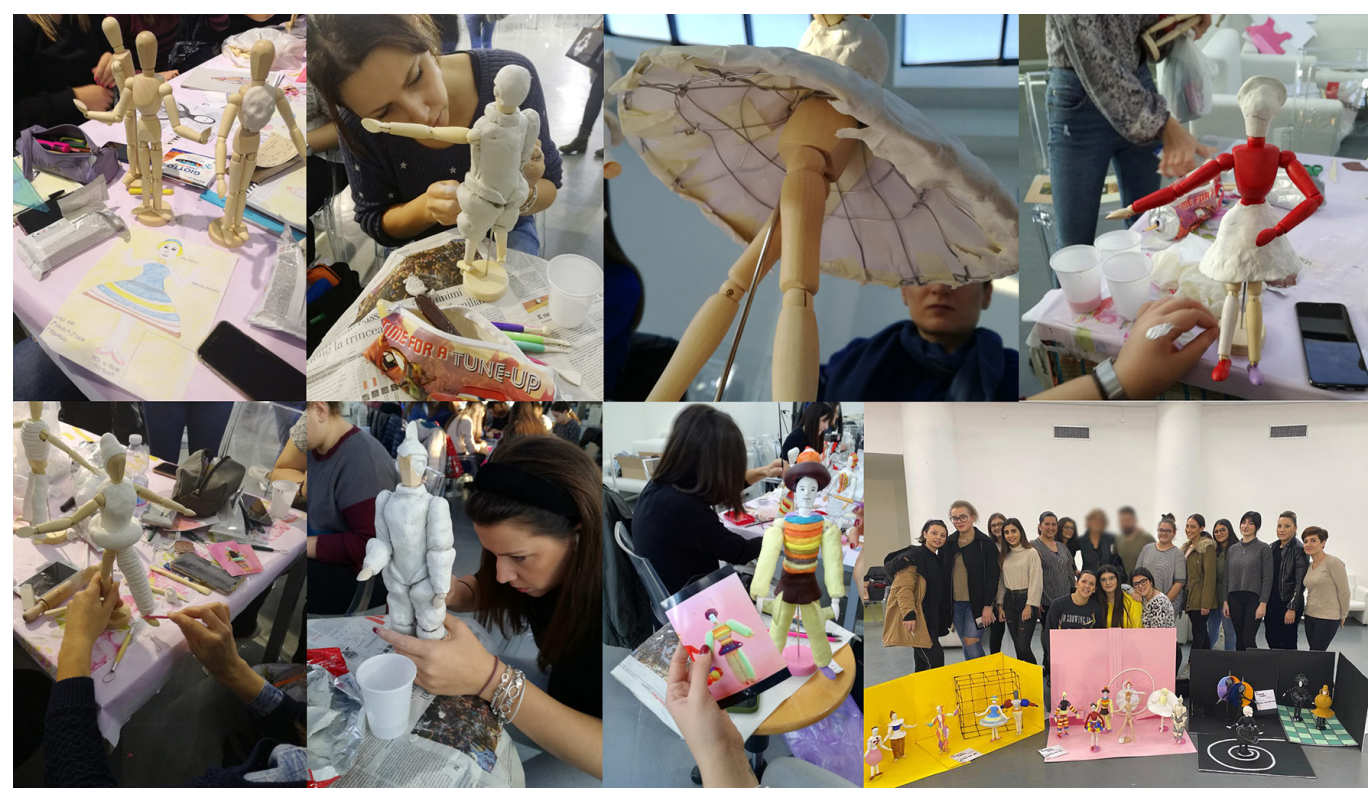

Il balletto in Stop-motion, la Realtà Virtuale e il Motion Tracking

Una volta ricreati i manichini e le macro-stanze, è stato possibile riaprire le danze. Attraverso la tecnica dello stop-motion (fig. 6), le Super-Marionette hanno ripreso vita frame dopo frame. Inoltre, per mezzo della tecnica dello Structure from Motion, i manichini sono stati acquisiti in digitale, rimodellati mediante le tecniche artigianali dello sculpting e forniti di struttura scheletrica (rigged models). Questo ha permesso di rielaborare non solo le movenze dei danzatori in un ambiente virtuale, ma soprattutto di trasferire i costumi-armatura su veri attori, per mezzo di appositi marker a contrasto (fig. 7). La tecnica del Motion tracking ha consentito, dunque, di ricreare in digitale insolite danze geometriche e inedite connessioni spaziali. Il workflow di lavoro è stato pensato per rispondere a un pubblico generico nell'ambito della fruizione museale [Panciroli 2016] e didattica, grazie proprio all'ausilio integrato delle più moderne tecnologie digitali e dell'ICT per il Cultural Heritage [Caprara, Guerra, Scala 2008]. 
Fig. 6. Animazione in stop-motion dei due personaggi della macro-stanza rosa (elaborazione digitale di A. Marraffa 2020)

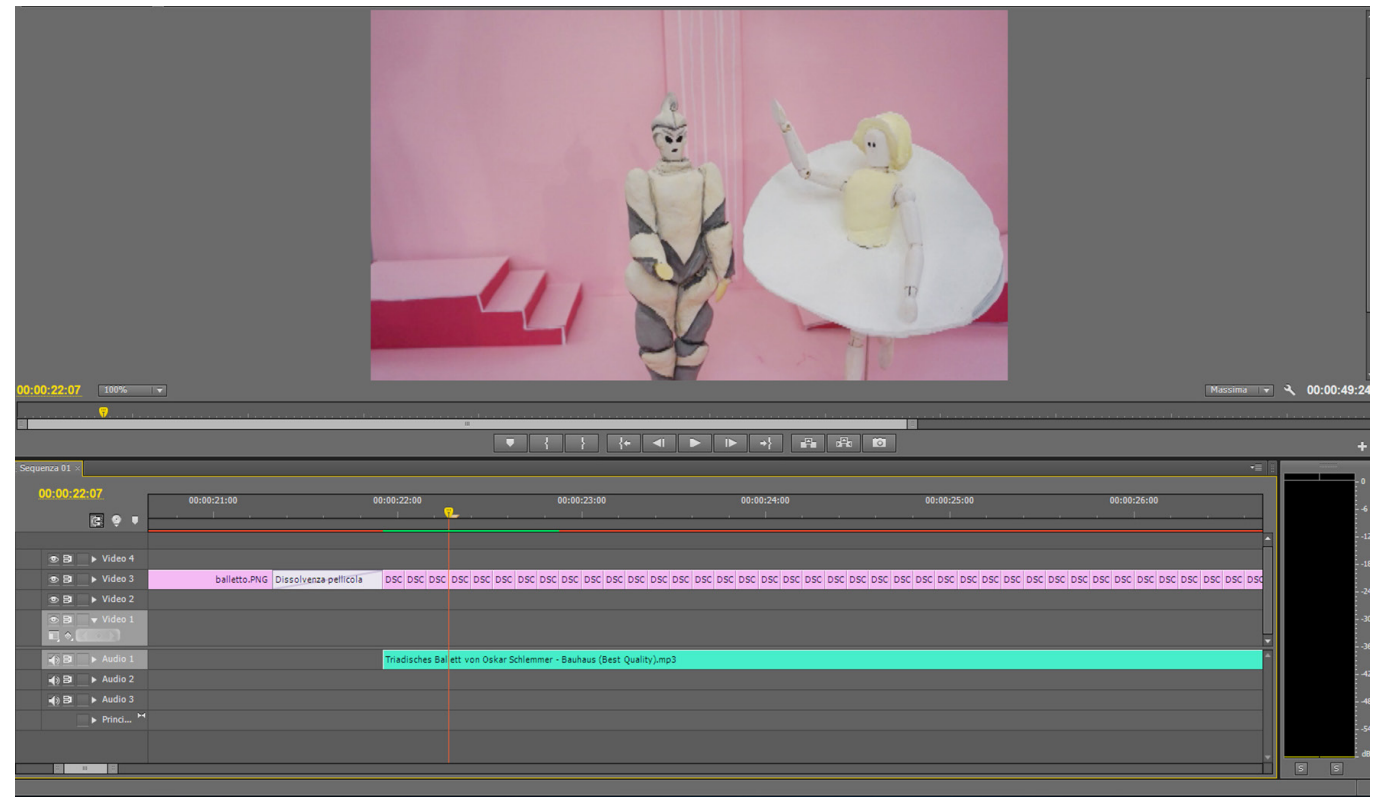

Litofanie, mappe tattili e stampe 3d: la 'lettura' aptico-tattile del Balletto triadico

La terza e ultima parte del workflow metodologico-applicativo è stata pensata per rispondere a un pubblico con esigenze speciale, in particolare, i disabili visivi e gli ipovedenti, al fine di rendere la comunicazione e la valorizzazione del balletto più inclusiva e democratica.

Per una persona ipo-vedente o non vedente, la porta di accesso preferenziale all'istanza edonistica ed estetica [5] di una qualsiasi azione o opera d'arte, è rappresentata dalle mani. La via tattile è una via inclusiva [6], spesso più efficace della vista [7], poiché permette di accedere a molte altre informazioni, le qualità tattili [8], che la vista da sola non è in grado di decifrare. Tuttavia il tatto va educato e orientato, secondo una precisa psicologia della percezione tattile [9].

Nel caso specifico della ricerca, la sfida della trasposizione è doppia, poiché si tratta di un balletto, quindi un'arte in movimento e in continuo divenire. Al fine di rendere il balletto comprensibile e fruibile anche da parte di un pubblico 'con esigenze speciali', sono state pensate alcune soluzioni per la fruizione tattile delle coreografie.
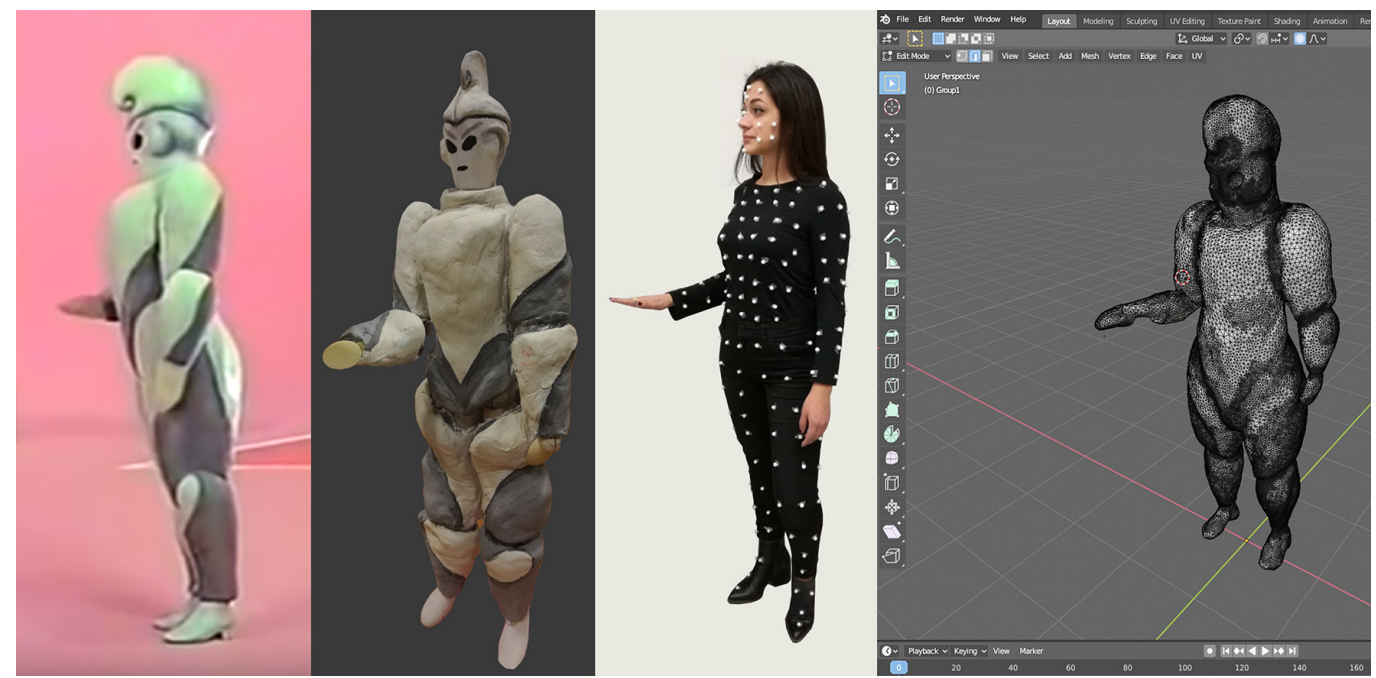

Fig. 7. Calibrazione del modello digitale sul modello anatomico tramite la tecnica del Motion Tracking (elaborazion Mollica). 
I) La prima è stata la creazione di cloni 3D dei manichini realizzati dagli studenti. Essi, dapprima acquisiti in digitale, sono stati in seguito stampati in PLA e adornati con stoffe di differenti texture.

2) La seconda ha visto la costruzione di mappe tattili e maquette tiflo-didattiche, che ricreano in pianta tutte le principali movenze compiute dai ballerini. Tali mappe, trasposizioni in 3D dei disegni autografi di Schlemmer, sono accompagnati da sintetiche descrizioni in Braille che meglio definiscono ogni sequenza o passaggio fondamentale.

3) La terza, infine, si è basata sulla elaborazione di litofanie e bassorilievi prospettici [I0] delle scene principali di ogni macro-stanza (fig. 8). Vige la regola del 'Vietato non toccare'. Le litofanie, stampate ancora una volta in 3D, a differenti altezze e profondità, ragionano per primi e secondi piani di lettura. Esse semplificano la scena e permettono un duplice grado di fruizione: aptico-tattile [I I] per i non vedenti, se toccate (fig. 9); aptico-visivo per i normodotati, se esposte in contro-luce (fig. I0).

Nell'era della società tecno-liquida e digitale, tutte queste strategie rientrano a pieno nella cosiddetta didattica ludica inclusiva, propria delle strategie di Edutainment per il Cultural Heritage, previste dalle principali linee guida Ministeriali ed Europee e finalizzate al superamento delle barriere tangibili, intangibili, digitali, materiali, immateriali, fisiche, senso-percettive, cognitive ecc.
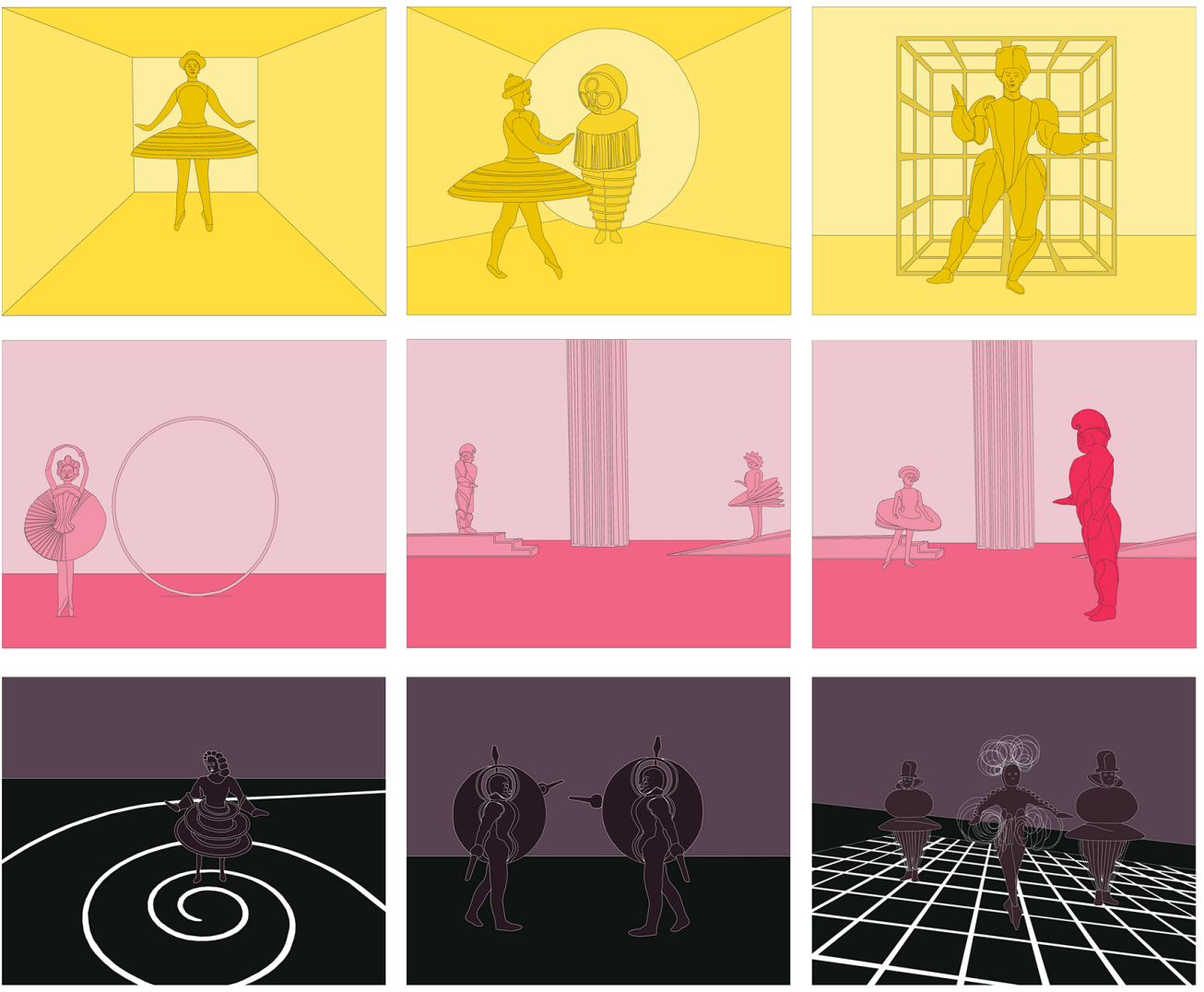

\section{Conclusioni e prospettive della Ricerca}

Come abbiamo potuto vedere "la mescolanza e la compenetrazione di uomo e spazio, difficilmente avviene in parti uguali [...]. II rapporto dell'uomo con lo spazio è in primo luogo tattile: esso è il percorrimento dello spazio e delle rigature spaziali in piani e volumi, che conferisce loro concretezza palpabile" [Schlemmer 1982]. II balletto triadico è pura 
Figg. 9, 10. Esempi di litofania con duplice grado fruizione: aptico-tattile e aptico-visiva (elaborazione digitale di A. Marraffa 2020). esperienza tattile e concreta, adornata e potenziata di molti altri valori sinestetici [Marazzi 2005] e ossimorici: le musiche colorate, le luci musicali, i balli statici, le statiche pose plastiche. Con estrema umiltà e rispetto, la Ricerca si accosta in maniera aperta all'opera di Schlemmer tentando di ricreare, grazie alle potenzialità del digitale, quell'anelito alla Super-marionetta moderna a cui lo stesso Schlemmer aspirava e che per mancanza di tempo e soldi non era riuscito a completare. L'impostazione multidisciplinare, multi-layered e multifocale [Brusaporci 20 I5] del progetto si auspica di ricreare, almeno in minima parte, quella monumentale bodengeometrie, la geometria del piano e delle connessioni, espressa dalle straordinarie figure del balletto triadico. Inoltre, l'epifania di forme e colori in movimento del balletto, tradotte in digitale e prodotte in analogico per mezzo della stampa 3D, si predispongono come consolidamento delle esperienze delle nozioni apprese.

Queste sono soltanto alcune delle possibili alternative e soluzioni, al fine di rendere il progetto più comprensibile e aperto a tutti, secondo una logica della cultura sempre più democratica, pedagogica, accessibile e inclusiva [12].
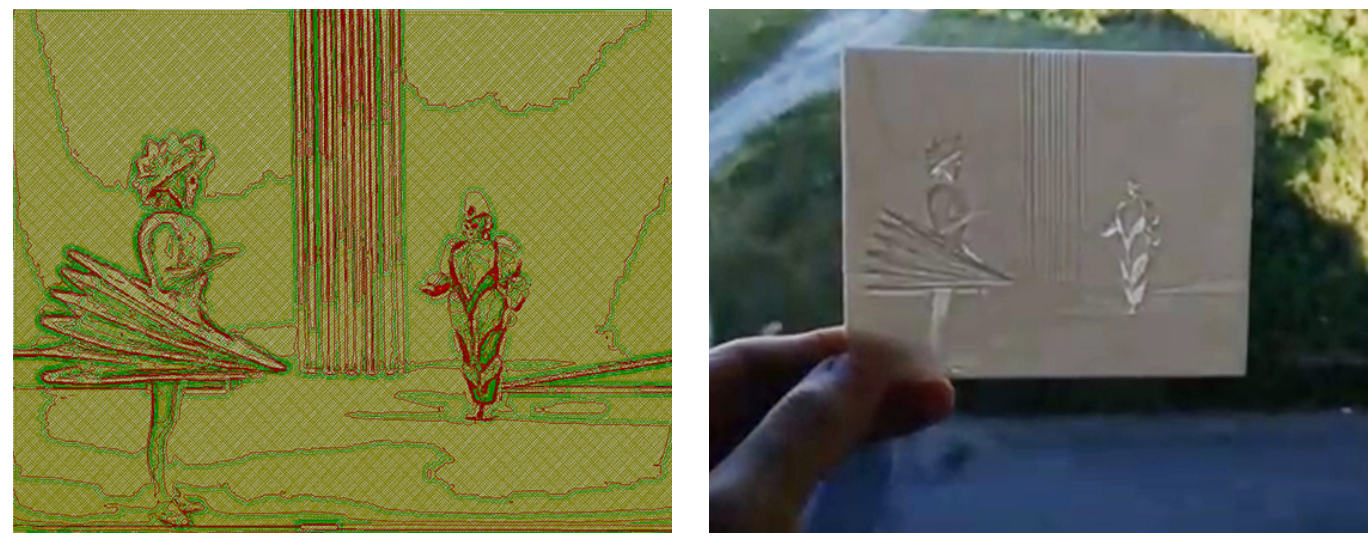

\section{Note}

[I] Nel programma di ricerca del Bauhaus, non poteva mancare, aspirando alla totalità artistica interdisciplinare, un laboratorio di sperimentazione nell'ambito del teatro, che come l'architettura, riunisce in sé, armoniosamente i diversi settori artistici. Per approfondire: Marina Bistolfi (a cura di). (1982). Oskar Schlemmer, Scritti sul teatro. Milano: Feltrinelli (prima edizione italiana).

[2] Le triadi sono evidenti: forma, colore, spazio; tre sono le dimensioni dello spazio, altezza, profondità, larghezza; tre sono le forme fondamentali: sfera, cubo, piramide; tre i colori primari dei costumi: rosso, giallo, blu: Bistolfi 1982.

[3] Schlemmer non vuole annichilire la figura umana, nascondendola da pesanti costumi. Egli piuttosto vuole esaltarla, schematizzandola attraverso poche linee, semplici ed essenziali: Bistolfi 1982.

[4] II workshop ha visto impegnati 18 studenti del primo anno, futuri maestri e pedagoghi della scuola primaria.

[5] Secondo Grassini, memoria-astrazione-memoria è il cerchio magico che consente di fruire esteticamente di un'immagine tramite il tatto: Grassini 2015.

[6] Se per il vedente il tatto è considerato un'appendice alla vista, per la persona non vedente la tattilità assume, dunque, una funzione gnosica: Galati 1992.

[7] II tatto riesce a raggiungere livelli di raffinatezza concorrenziali con la vista: Grassini 2015.

[8] Tra le qualità tattili più importanti, si citano: la temperatura, il peso, la texture, ecc.

[9] La percezione tattile integrata dipende dalla capacità del fruitore di stabilire connessioni tra le parti percepite. Questo meccanismo di integrazione, nella percezione cenestesica, ovverosia tattile motoria, non ha la stessa immediatezza di quella visiva: Grassini 2006

[I0] Nella 'lettura' tattile, percezione, cognizione e significazione, sono le tre tappe principali dell'interpretazione estetica di un'immagine.

[ I I ] II dispositivo aptico-tattile consente all'utente di manipolare il prodotto 3d. In tal misura, l'esplorazione tattile, si basa sul paradigma di fruizione del 'learning by doing or by interacting': Rowe, Guilford 1999.

[12] La sfida odierna è proprio quella di ribaltare il rapporto univoco tra $\mathrm{CH}$ e visitatore, offrendo invece nuovi processi cognitivi, multisensoriale, basati su innovazione tecnologica e tradizione, aprendo la strada a un vero e proprio coinvolgimento sensoriale ed emozionale: Cervellini, Rossi 2011. 


\section{Riferimenti bibliografici}

Antinucci Francesco (2013). Comunicare nel museo. Bari: Laterza.

Arnheim Rudolf (1994). Per la salvezza dell'arte.Ventisei saggi. Milano: Feltrinelli.

Benjamin Walter (2000). L'opera d'arte nell'epoca della sua riproducibilità tecnica. Torino: Piccola Biblioteca Einaudi.

Bistolfi Marina (a cura di). (1982). Scritti sul teatro di Oskar Schlemmer. Milano: Feltrinelli.

Bobbio Andrea, Scurati Cesare (2008). Ricerca pedagogica e educazione educativa. Roma: Armando Editore.

EmplerTommaso (20 I7). ICT per il Cultural Heritage. Rappresentare, Comunicare, Divulgare. Roma: DEI - Tipografia Genio Civile. Gregory Richard L. ( 1966). Occhio e cervello. La psicologia del vedere. Milano: II Saggiatore.

Hollins Mark (1989). Understanding blindness: an integrative approach. Hillsdale (NJ): Lawrence Erbaum Associates.

Grassini Aldo (20 I5). Per un'estetica della tattilità. Ma esistono davvero le arti visive? Roma: Armando editore.

Hatwell Yvette (2006). II tatto e l'accesso manuale ai beni culturali. In Museo Tattile Statale di Ancona (a cura di). Atti del convegno L'arte a portata di mano. Verso una pedagogia di accesso ai beni culturali senza barriere. Portonovo di Ancona, 21 -23 ottobre 2004. Roma: Armando Editore.

Hooper-Greenhill Eilean (1994). The education role of the museum. London: Routledge.

Martini Berta (20 I6). Dispositivi ICT e musei. Efficacia formativa dell'esperienza di fruizione. In Martini Berta. II Museo Sensibile. Le tecnologie ICT al servizio della trasmissione della conoscenza. Milano: Franco Angeli.

Museo Tattile Statale di Ancona (a cura di). (2006). L'arte a portata di mano. Verso una pedagogia di accesso ai beni culturali senza barriere. Roma: Armando Editore.

Panciroli Chiara (2016). Le professionalità educative tra scuola e musei. Milano: Guerini.

Secchi Loretta (2004). L'educazione estetica per l'integrazione. Roma: Carrocci Faber.

Sennett Richard (2008). L'uomo artigiano. Milano: Feltrinelli.

Autore

Andrea Marraffa, Università degli Studi Mediterranea di Reggio Calabria, andreamarraffa89@yahoo.it

Per citare questo capitolo: Marraffa Andrea (2020). Das Triadisches Ballett reloaded: l'opera di Schlemmer al servizio di nuove connessioni spaziali e didattiche/Das Triadisches Ballett reloaded: Schlemmer's total pièce at the service of new spatial and didactic connections In Arena A., Arena M., Brandolino R.G., Colistra D., Ginex G., Mediati D., Nucifora S., Raffa P. (a cura di). Connettere. Un disegno per annodare e tessere. Atti del $42^{\circ}$ Convegno Internazionale dei Docenti delle Discipline della Rappresentazione/Connecting. Drawing for weaving relationships. Proceedings of the 42th International Conference of Representation Disciplines Teachers. Milano: FrancoAngeli, pp. 626-643. 


\title{
Das Triadisches Ballett Reloaded: Schlemmer's Total Pièce at the Service of New Spatial and Didactic Connections
}

\author{
Andrea Marraffa
}

Abstract

A hundred years after the birth of the Bauhaus, the Triadic Ballet continues to fascinate and make school. The gestures, the dances, the geometries, the shapes, born from the visionary and multifaceted genius of Oskar Schlemmer appear, today more than ever, current and innovative. In a synesthetic combination of colors, sounds, scents, emotions, the Ballet is a synonymous of an educational, multi-sensorial and multi-disciplinary laboratory. All this is part of a huge theatrical stage machine, typical of a complex material culture, capable of connecting the Apollonian and the Dionysian, the color and the light, the drawing and the music, man and architecture. The research aims to describe the activities of an educational laboratory created within the course of 'Scienze della Formazione Primaria' and carried out at the Mediterranean University of Reggio Calabria, entitled Das Triadisches Ballett reloaded 3.0. The project aims to 'recharge' Schlemmer's theatrical artwork, enhancing it through the modern dissemination and communication techniques of the $\mathrm{CH}$. The Triadic Ballet comes to life again thanks to tailored mannequins, dressed in clay, adorned with pure shapes and painted in primary colors. The yearning for the life of the Schlemmerian Super-Marionette allows to invent new digital ballets, obtained through the Stop-Motion, through the Virtual Reality and the Motion Tracking. The last part of the research is aimed at identifying innovative strategies for the Ballett's accessibility and the dissemination, also for people 'with special needs', in particular the visually impaired and the full blind people. Tactile maps, 3D prints, lithophanies and multi-sensorial synaesthesias are the privileged tools for 'dynamic reading' of the choreography, in order to make their universal, democratic and inclusive fruition.

Keywords

Bauhaus, Triadic-Ballett, stop-motion, didactic, accessibility.
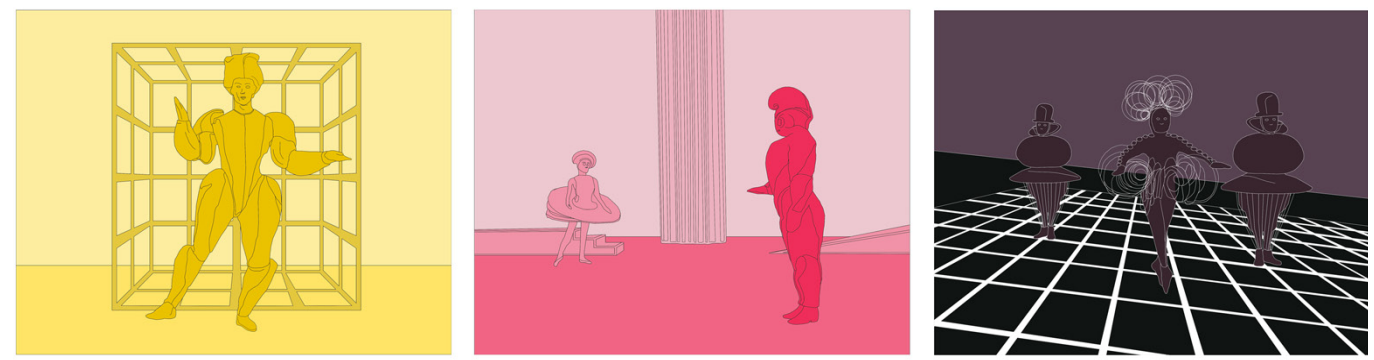


\section{Oskar Schlemmer and the Bauhaus's theater}

The artistic poetics of the Bauhaus theater still represents a current topic of considerable interest due to its strong implications in the artistic, didactic and pedagogical fields. In the Bauhaus school, Oskar Schlemmer was a proto-Cubist painter, a sculptor, a master craftsman of carvings, a director, a choreographer, a set designer, and much more. His multifaceted artistic personality contributed to the creation of a new total and multi-disciplinary type of art which identified in the dance, and in particular in modern ballet, the highest and most important expressive element: the preferential way to tell the space, the architecture, the man. Schlemmer's idea of theater, with a total [I], reformist and democratic breath, typical of the artistic ideology that unfolded itself within the Weimar Republic, was based on a school of construction, oriented towards the incessant didactic experimentation and contamination between different genres. For Schlemmer, director of the Bauhaus-buhne from 1923 to 1929, the ballet was the perfect synthesis of music, geometry, theater and dance. The shapes and the primary colors allowed the exaltation of the human figure, projecting on the stage new metaphysical visions, dreamlike certainties and inexorable attempts to redeem humanity against the growing push towards mechanization of the $X X$ century. Schlemmer looked at Kandinsky's scenography and at the chromatic and abstract dramas, stealing the expressive and incisive power of colors; he was inspired by the utopian thrusts of total mechanization of Moholy-Nagy; he was able to condense a series of attributes of a modern artistic anthropocentric in the Klee's puppet.

In his early drawings and sculptures, those pure formal elements derived from Russian constructivism were evident, but also those faceless figures of the proto-Cubist and analytical cubist painters, (Picasso above all), and again, the continuous chromatic games of the late Impressionists, in particular Holzel, and last but not least, the influence of the metaphysical art by De Chirico, in which the human figure was no longer just an empty mask or a wooden skeleton, but it was once again the ultimate aim of the total art. Schlemmer's continuous scientific research, aimed at conquering an educational and didactic theorizing of the perfect theatrical form, based on the exaltation of the conscience and knowledge of the strength of its most elementary artistic means - the line, the shape and the color - through their distribution in space and in continuous relationship with human figures. The Schlemmerian style is an expression of synaesthetic connections between colors, sounds, lines, geometries, movements, emotions. An artistic evolution that condenses and materializes itself in what it has always been considered as his masterpiece: the Triadic Ballet (fig. I).

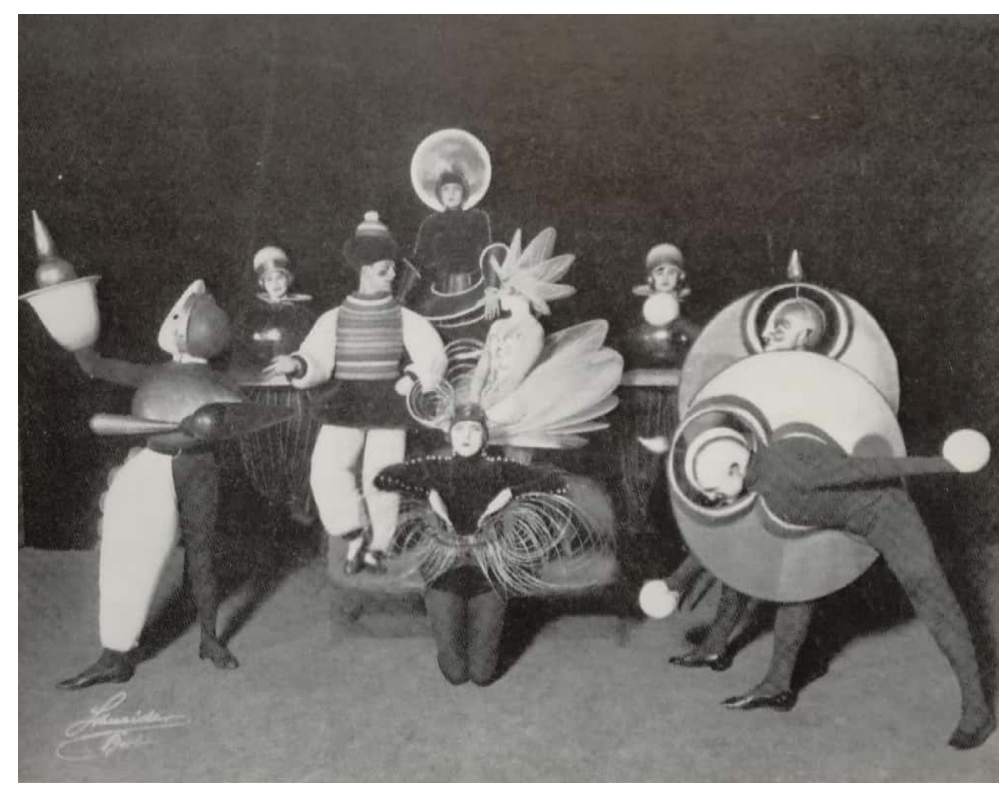


The Triadic Ballet: connections between space and light, sound and color, man and architecture

The Triadic Ballet, in German Das Triadisches Ballett (fig. I), is unanimously considered as the masterpiece of Schlemmerian poetry. The result of continuous laboratory experiments, the ballet is the emblem of the didactic and multidisciplinary research of the Bauhaus theater. Schlemmer conceives the ballet as a supreme and total art form, the only worthy heir of the ancient Greek theatrical forms. The Ballet is the dance of the triad, exchange of the One, Two and Three: the human figure in form, color, movement and sound. For Schlemmer, the 'three' appears as the kabbalistic number par excellence, a metaphor for overcoming the self-centeredness, the annihilating the contrast of dualities and the principle of collective actor collaboration. The Triadic Ballet is pure numerical connection [2]: the choreographies of which it is composed, in triple agreement and according to a multiple and magical succession of prime numbers ( $1-5-7$ etc.), they put on stage eighteen costumes within twelve sub-rooms (fig. 2), alternating, one or three dancers at a time. The actors are dehumanized, androgynous figures, often masked, which sinuously twirl with their mechanical movements, making and completing geometric choreography. There are three macro-rooms, aseptic and furnished with few architectural elements, extensions of the human limbs. Three are also the main colors of the rooms: yellow, pink and black, to which correspond as many different musical compositions, respectively of comic-burlesque character (yellow room), ceremonious-solemn (pink room), magical-metaphysical-fantastic (black room).

In the different rooms, the dancers adorned with costumes very similar to gawky and clumsy armature, perform a real total gestural geometrization. Human figures are idealized, almost over-individual, endowed with stylized expressive attitudes and reduced to the bone [3].

Similar to Seurat's geometric manikins, Schllemmer's dancers are arranged on the scene "like pawns on a chessboard, with a rhythm of intervals calculated almost mathematically, in a composition built on the horizontal and vertical lines" [Argan anno....pp..... . Man, the measure of everything, is a geometric projection of the space around him (fig. 3). The dancers, almost always seen in front, in profile or from behind, are enclosed within their
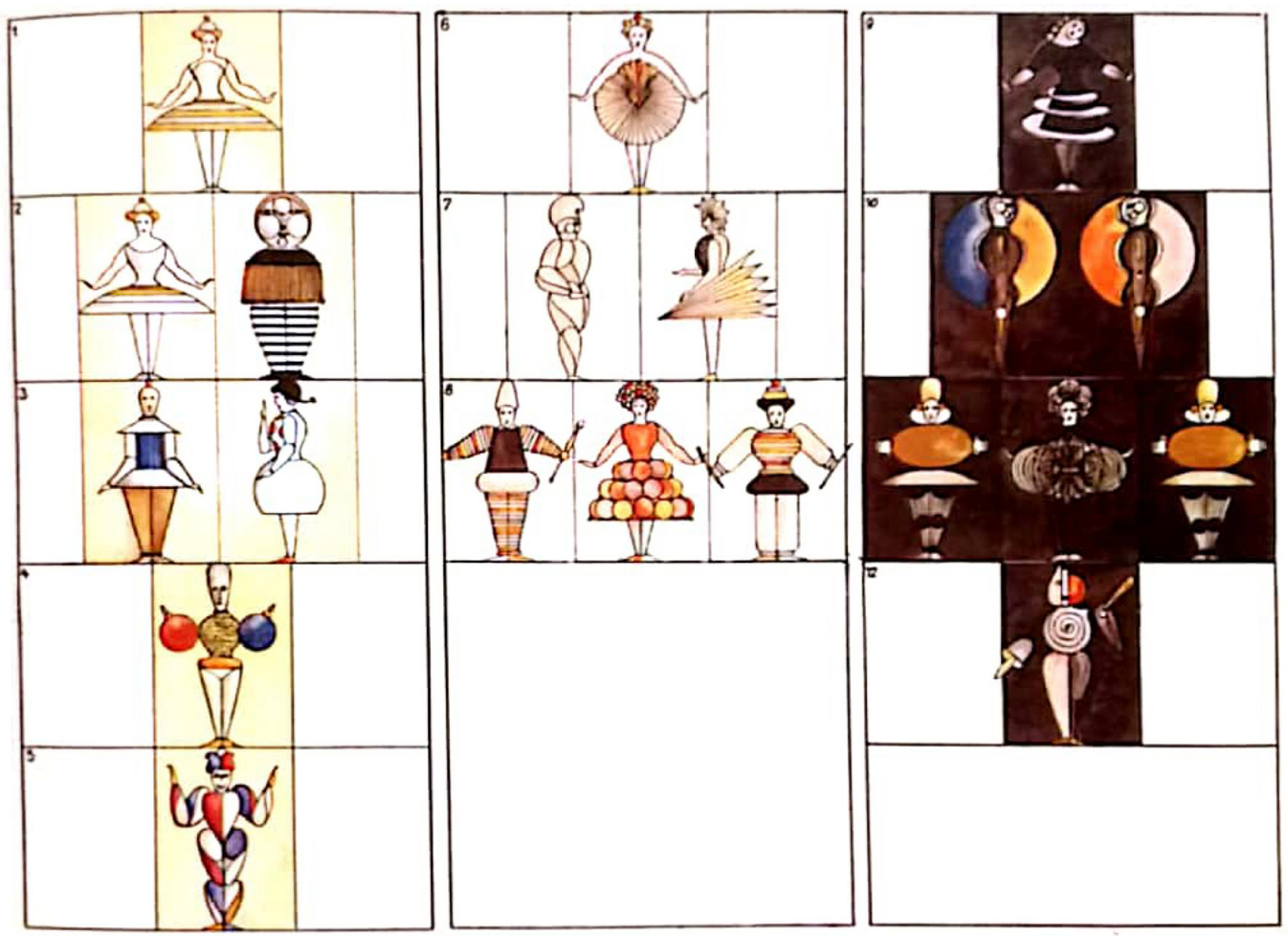
Fig. 3. Geometric anthropocentric visions by 0 . armor-costumes. Similar to real moving architectures, they stereometrically abstract the shapes and functions of the human body. The bodies build geometries of glances, dialogue with the surrounding space in a constant search for synesthetic connection between architecture, sound and space.

An orgiastic and Dionysian thiasos, in which remains, however, that Apollonian vision of a geometric world, made of precise mathematical correspondences and proportional connections between man and space.

The costume-armor, the music, the colors, the shapes and the primary colors, are for Schlemmer the preferential tools to develop the geometry of the scene, in order to compose those connections and the stereometric projections in movement of their visions. Schlemmer's dancers define and trace a real movement's grammar, made up of many movements, gestures, formal and synaesthetic connections, in a continuous and delicate 'unstable balance' between opposing forms, music and colors: coherent performances between sense and nonsense of the human act.
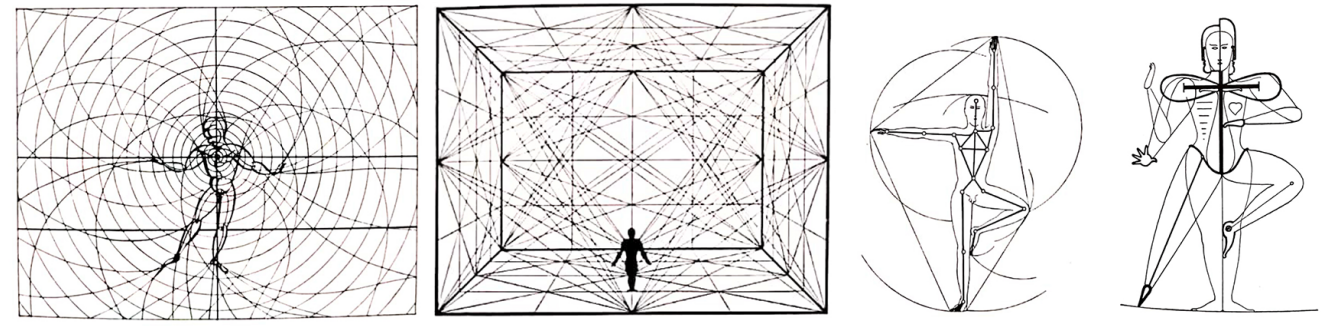

Fig. 4. 'Anatomical eidotypes': drawings and preliminary sketches of plastic models (drawings were made by the students were made by the students Visual Communication and Primary education sciences' Primary education sciences course)

\section{The Triadic Ballet 3.0 Reloaded: the pursuit of new didactic connections}

The research, presented below, tells about the experience of a didactic and multidisciplinary laboratory, created within the course of 'Design and visual communication' [4], entitled Das Triadische Ballett reloaded. Theater, dance and architecture in stop-motion ", carried out at the 'Mediterranean' University of Reggio Calabria, in December 2019.

The project was designed to meet the needs of three different audiences:

I) the students of the SdFP course; 2) a general public, user and recipient of the cultural and museum offer; 3 ) the public with 'special needs', in particular the visually impaired and full blind people.

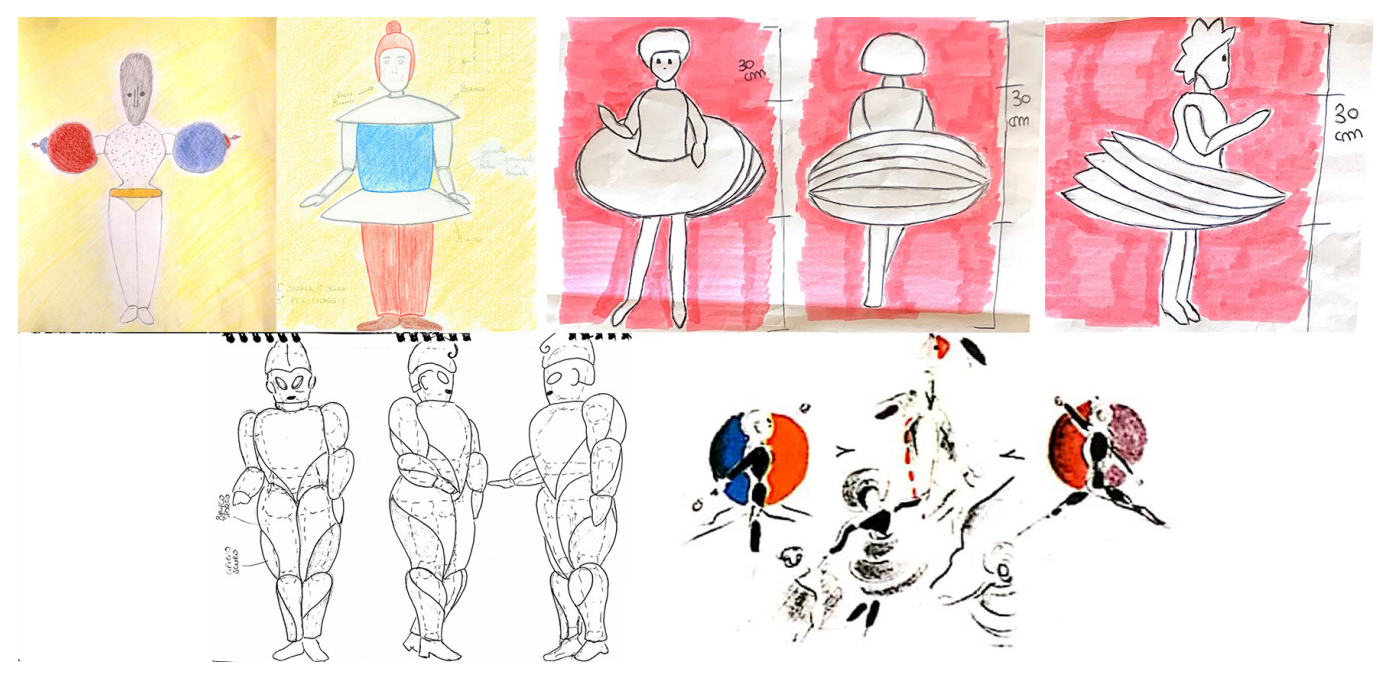


The didactic laboratory, the mannequins and the Triadic Ballet 3.0

In virtual didactic connection, the first target of audience identified by the project is double: on the one hand there are the potential future teachers, current students of the degree course in Primary Education Sciences; on the other hand, there are the elementary school children, who are also recipients of the pedagogical offer. Once the theme of the workshop was presented, each student was assigned a dancer from the Schlemmer ballet, with the aim to recreate their main features and movements.

Starting from precise preliminary studies, the students began to dialogue with the tools of analog design: sections, ortho-plans, perspectives, etc. The 'anatomical eidotypes' (fig. 4) of the Schlemmerian androgynous dancers were the basis for the creation of a real plastic model.

On the wooden tailored mannequins Schlemmer's awkward and twisted costumes-armor were recreated, made of white clay, fabric, paper-mache and, later, colored with bright primary colors in tempera (fig. 5). As already mentioned, the main objective of the project is to 'recharge' and enhance Schlemmer's work, through the modern dissemination and communication techniques of the $\mathrm{CH}$, while at the same time preserving a strong artisan component. This is what Richard Sennett indicated as the qualities of homo laborans enhanced by the homo faber's technique [Sennett 2008]. Once the eighteen models were made, the sets of the three macro-rooms were built, in order of appearance, in yellow, pink and black respectively.

Fig. 5. Realization of Schlemmerian characters by students of the Primary Education Science course.

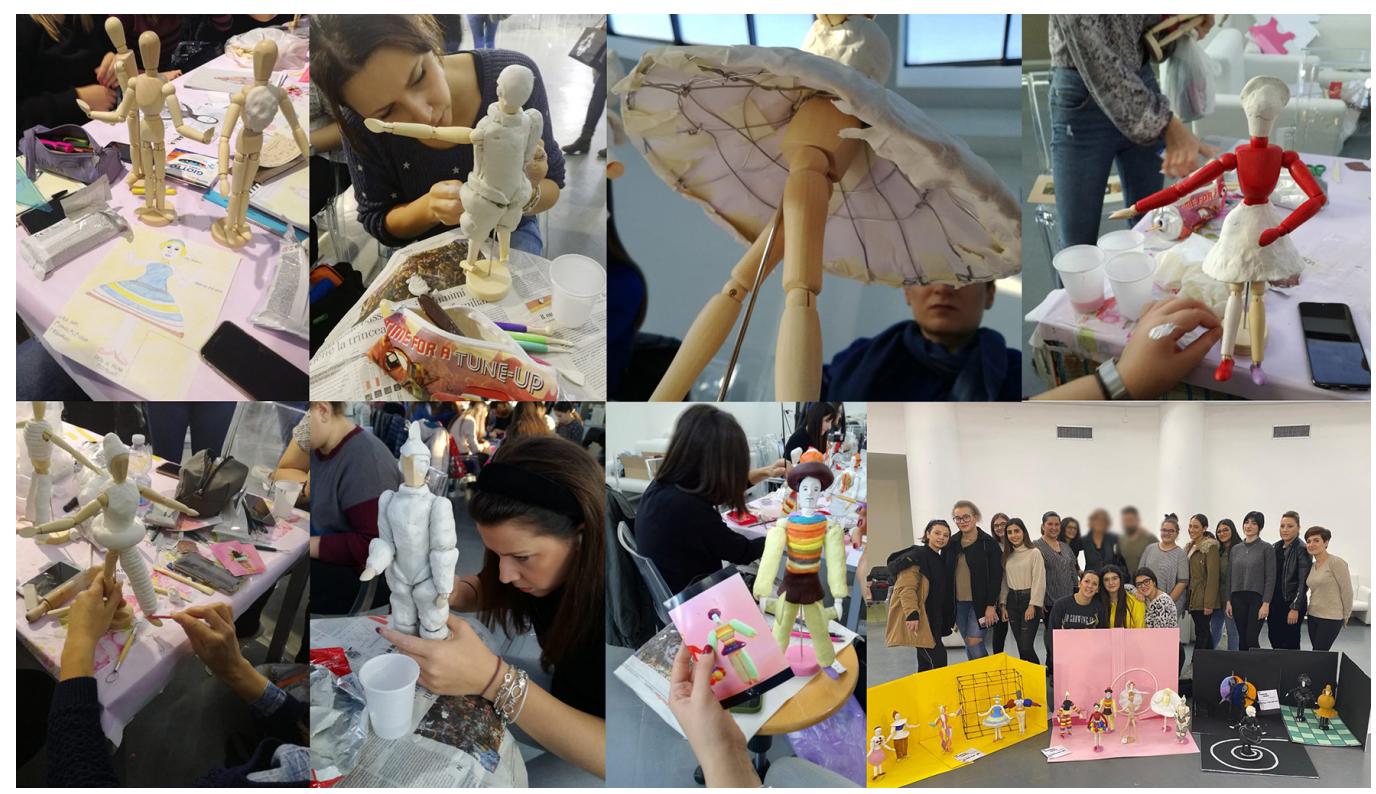

The ballet in Stop-motion, the Virtual Reality and the Motion Tracking

Once the mannequins and macro-rooms were recreated, it was possible to reopen the dances. Through the stop-motion technique (fig. 6), the Super-Marionettes have resumed life frame after frame. Furthermore, by means of the Structure from Motion technique, the mannequins were digitally acquired, remodeled using the artisan techniques of Sculpting and provided with skeletal structure (rigged models). This made it possible to rework not only the movements of the dancers in a virtual environment, but above all to transfer the costumes-armor to the real actors, by means of special contrasting markers (fig. 7). The motion tracking technique has therefore made it possible to digitally recreate unusual geometric dances and unusual spatial connections. The workflow was thought to respond to a general public in the context of common museum enhancement [Panciroli 2016] and teaching, thanks to the integrated help of the most modern digital technologies and ICT for Cultural Heritage [Caprara, Guerra, Scala 2008]. 
Fig. 6. Stop-motion animation of the two characters of the pink macro-room (digital elaboration by A. Marraffa 2020).
Fig. 7. Calibration of the digital model on the anatomical model using the Motion Tracking technique (digital elaboration

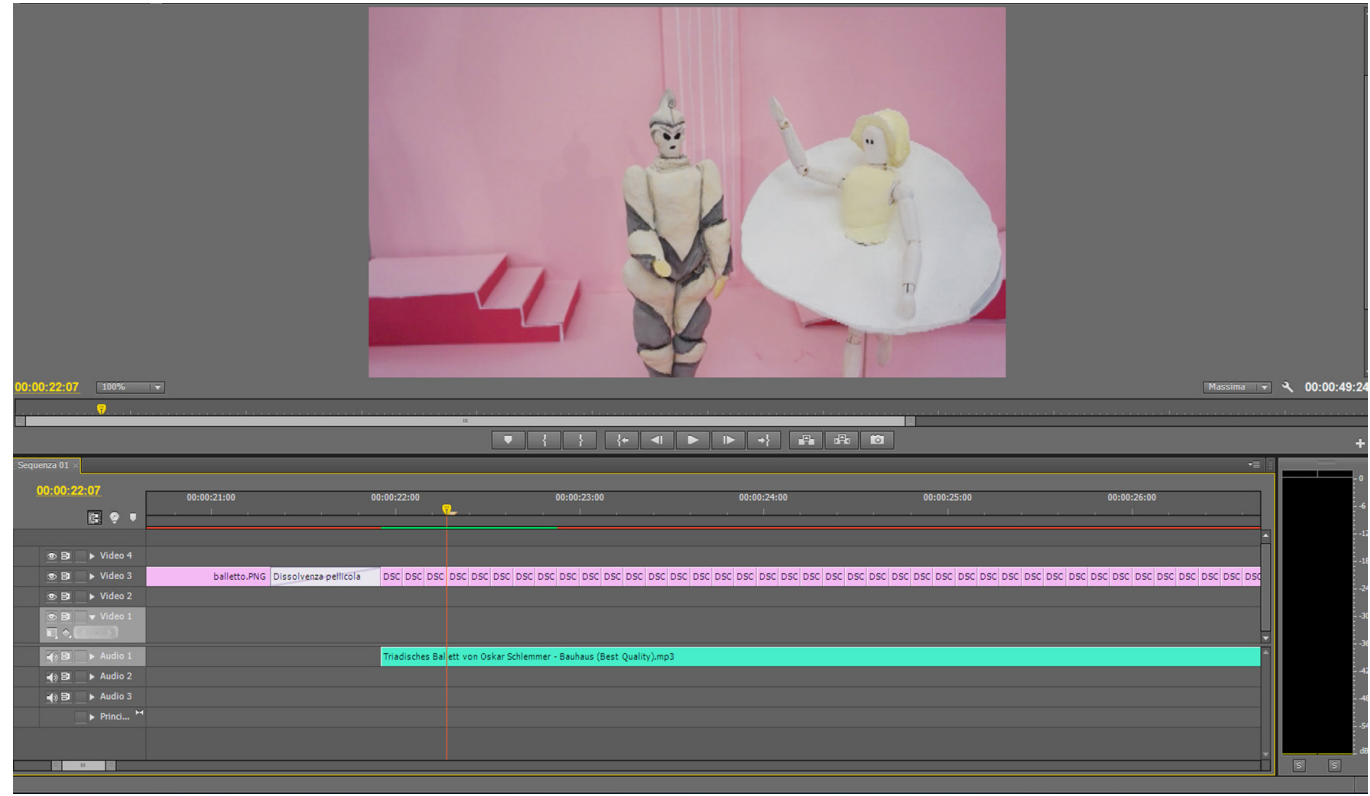

Lithophanies, tactile maps and 3d prints: the haptic-tactile 'reading' of the Triadic Ballet The third and final part of the methodological-application workflow has been designed to respond to an audience 'with special needs', in particular, the visually impaired and partially sighted people, in order to make communication and enhancement of ballet more inclusive and democratic.

For a visually impaired or a blind person, the preferential access door to the hedonistic and aesthetic [5] instance of any action or work of art is represented by the hands. The tactile way is an inclusive way [6], often more effective than sight [7], since it allows you to access to many other information, the tactile qualities [8], which the sight alone is unable to decipher. However, touch must be educated and oriented, according to a precise psychology of tactile perception [9].

In the specific case of the research, the challenge of this transposition is double, since it is a ballet, therefore an art in movement and in constant evolution. In order to make the ballet comprehensible and usable even by an audience 'with special needs', some solutions have been designed for the tactile use of the choreography.
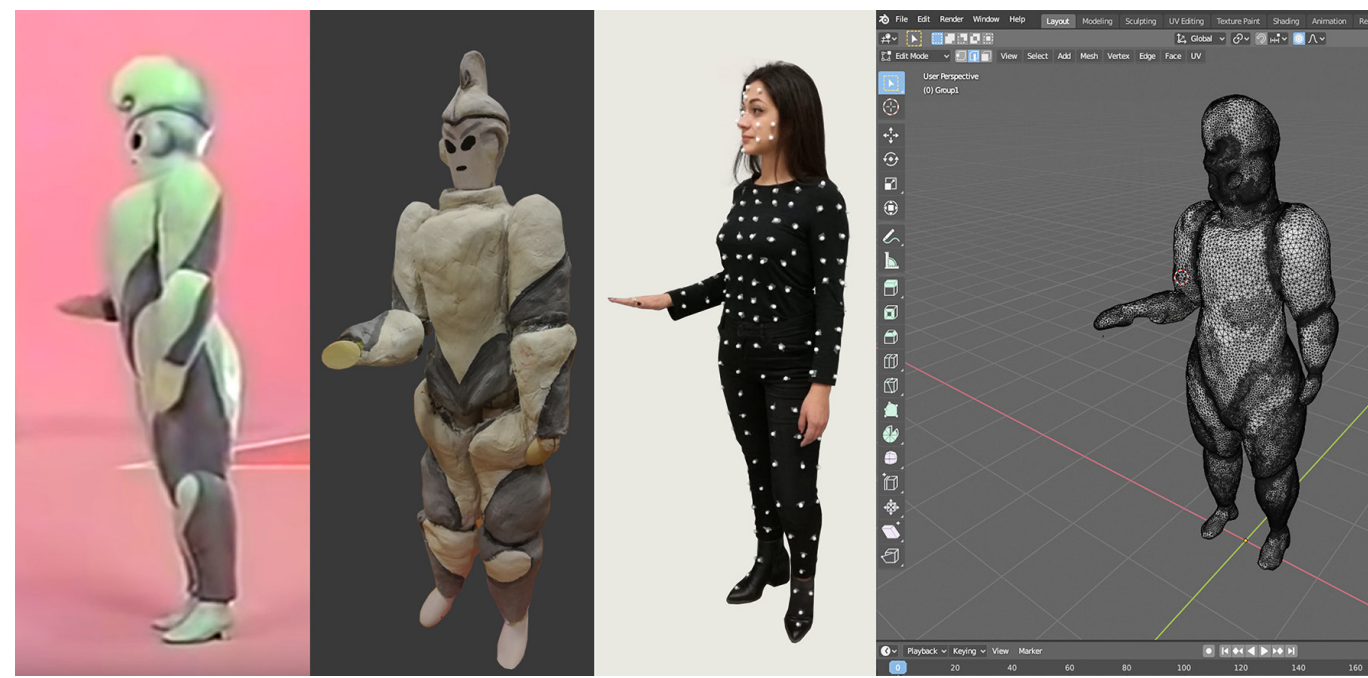
1) The first one was the creation of 3D clones of the mannequins made by the students. They, first acquired digitally, were subsequently printed in PLA and adorned with fabrics of different textures.

2) The second one saw the construction of tactile maps and typho-didactic maquettes, which recreate in plan all the main movements performed by the dancers. These maps, 3D transpositions of Schlemmer's autograph drawings, are accompanied by synthetic descriptions in Braille that best define each fundamental sequence or passage.

3) Finally, the third one was based on the elaboration of lithophanies and perspective bas-reliefs [I0] of the main scenes of each macro-room (fig. 8). The 'Do not touch' rule applies. The lithophanies, once again printed in 3D, at different heights and depths, think for first and second reading plans. They simplify the scene and allow a double degree of use: haptic-tactile [I I] for the blind, if touched (fig. 9); haptic-visual for able-bodied people, if exposed in counter-light (fig. 10).

In the era of a techno-liquid and digital society, all these strategies are fully part of the so-called inclusive educational teaching, proper of the Edutainment strategies for the Cultural Heritage, foreseen by the main Ministerial and European guidelines and aimed at overcoming tangible, intangible barriers digital, material, immaterial, physical, sense-perceptive, cognitive etc.
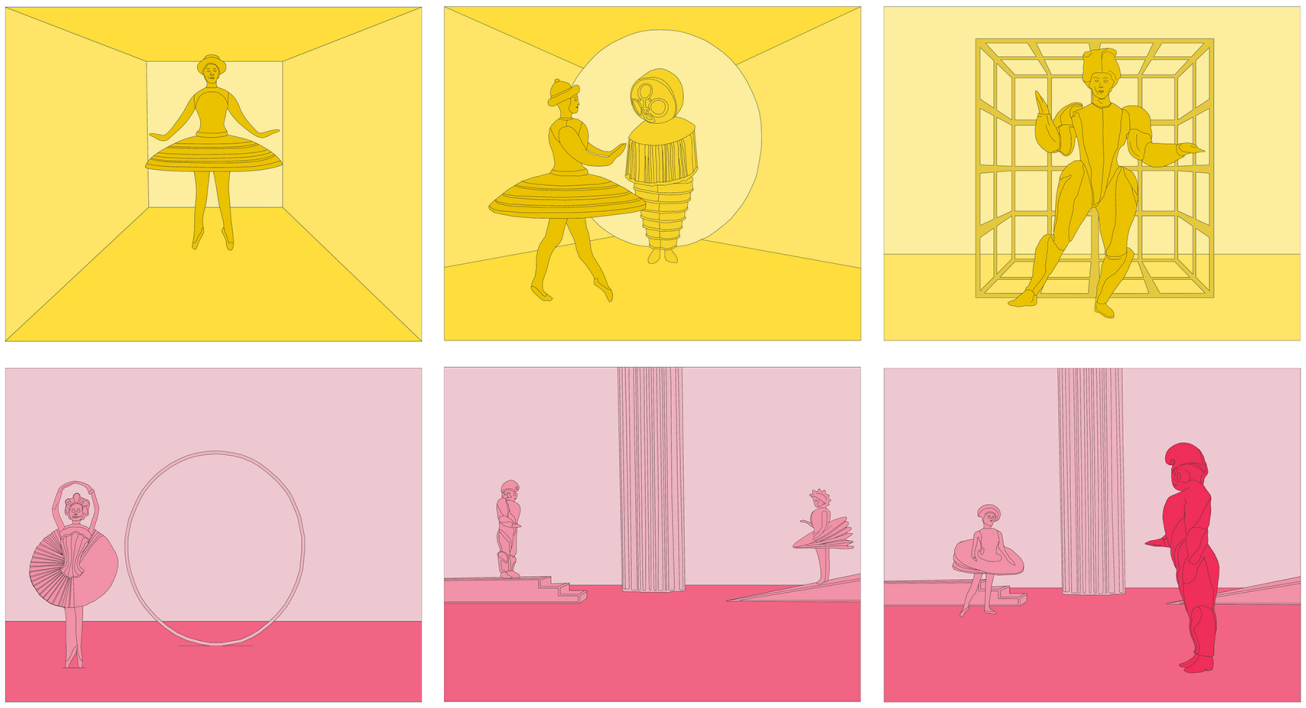

Fig. 8. Lithophanies and perspective bas-reliefs of the main scenes of each macro-room (digital elaboration by A. Mital ela2020)
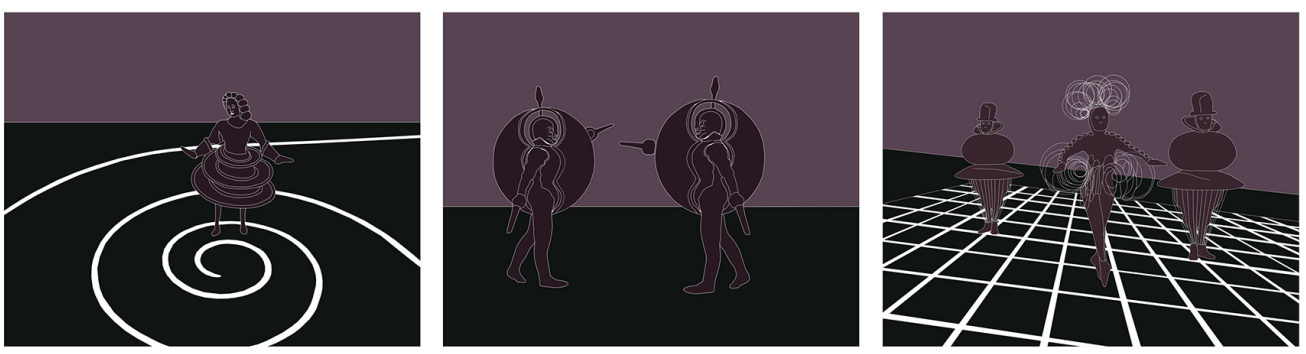

\section{Conclusions and perspectives of the research}

As we have seen "the mixing and interpenetration of man and space, hardly occurs in equal parts' [...].'Man's relationship with space is primarily tactile: it is the traversing of space and spatial stripes in planes and volumes, which gives them palpable concreteness" [Schlemmer 1982]. The Triadic Ballet, as we have seen, is a pure tactile experience, adorned and enhan- 
Figs. 9, 10. Examples of lithophany with two degrees of use: haptic-tactile and haptic-visual (digital elaboration by di A. Marraffa 2020) ced with many other synaesthetic [Marazzi 2005] and oxymoronic values: the 'colored music', the 'musical lights', 'the static dances', 'the static plastic poses'.

With extreme humility and respect, the Research approaches Schlemmer's work in an open way, attempting to recreate, thanks to the potential of digital technology, that yearning for the modern Super-puppet to which Schlemmer himself aspired and which for lack of time and money had failed to complete. The multi-disciplinary, multi-layered and multi-focal setting [Brusaporci 20 I5] of the project hopes to recreate, at least in a minimal part, that monumental bodengeometrie, the geometry of the plane and the connections, expressed by the extraordinary figures of the Triadic Ballet. In addition, the epiphany of moving shapes and colors, translated into digital and produced in analogue by means of the 3D printing, are prepared as a consolidation of the experiences of the notions learned.

These are just some of the possible alternatives and solutions, in order to make the project more understandable and open to everyone, in according to an increasingly democratic, pedagogical, accessible and inclusive logic of the culture [12].
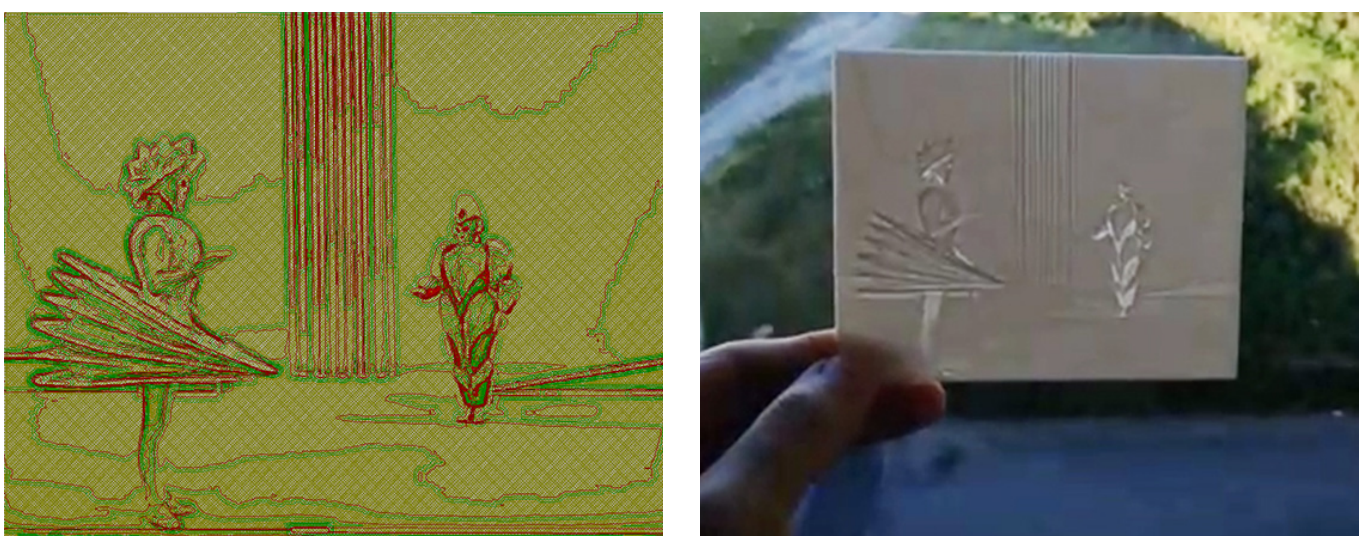

\section{Notes}

[ I ] Nel programma di ricerca del Bauhaus, non poteva mancare, aspirando alla totalità artistica interdisciplinare, un laboratorio di sperimentazione nell'ambito del teatro, che come l'architettura, riunisce in sé, armoniosamente i diversi settori artistici. Per approfondire: Marina Bistolfi (a cura di). (1982). Oskar Schlemmer, Scritti sul teatro. Milano: Feltrinelli (prima edizione italiana)

[2] Le triadi sono evidenti: forma, colore, spazio; tre sono le dimensioni dello spazio, altezza, profondità, larghezza; tre sono le forme fondamentali: sfera, cubo, piramide; tre i colori primari dei costumi: rosso, giallo, blu: Bistolfi 1982

[3] Schlemmer non vuole annichilire la figura umana, nascondendola da pesanti costumi. Egli piuttosto vuole esaltarla schematizzandola attraverso poche linee, semplici ed essenziali: Bistolfi 1982.

[4] II workshop ha visto impegnati 18 studenti del primo anno, futuri maestri e pedagoghi della scuola primaria.

[5] Secondo Grassini, memoria-astrazione-memoria è il cerchio magico che consente di fruire esteticamente di un'immagine tramite il tatto: Grassini 2015.

[6] Se per il vedente il tatto è considerato un'appendice alla vista, per la persona non vedente la tattilità assume, dunque, una funzione gnosica: Galati 1992.

[7] II tatto riesce a raggiungere livelli di raffinatezza concorrenziali con la vista: Grassini 20 I 5.

[8] Tra le qualità tattili più importanti, si citano: la temperatura, il peso, la texture, ecc.

[9] La percezione tattile integrata dipende dalla capacità del fruitore di stabilire connessioni tra le parti percepite. Questo meccanismo di integrazione, nella percezione cenestesica, ovverosia tattile motoria, non ha la stessa immediatezza di quella visiva: Grassini 2006

[I0] Nella 'lettura' tattile, percezione, cognizione e significazione, sono le tre tappe principali dell'interpretazione estetica di un'immagine.

[ I I ] II dispositivo aptico-tattile consente all'utente di manipolare il prodotto 3d. In tal misura, l'esplorazione tattile, si basa sul paradigma di fruizione del 'learning by doing or by interacting': Rowe, Guilford 1999.

[12] La sfida odierna è proprio quella di ribaltare il rapporto univoco tra $\mathrm{CH}$ e visitatore, offrendo invece nuovi processi cognitivi, multisensoriale, basati su innovazione tecnologica e tradizione, aprendo la strada a un vero e proprio coinvolgimento sensoriale ed emozionale: Cervellini, Rossi 2011. 


\section{References}

Antinucci Francesco (20।3). Comunicare nel museo. Bari: Laterza.

Arnheim Rudolf (1994). Per la salvezza dell'arte.Ventisei saggi. Milano: Feltrinelli.

Benjamin Walter (2000). L'opera d'arte nell'epoca della sua riproducibilità tecnica. Torino: Piccola Biblioteca Einaudi.

Bistolfi Marina (a cura di). ( 1982). Scritti sul teatro di Oskar Schlemmer. Milano: Feltrinelli.

Bobbio Andrea, Scurati Cesare (2008). Ricerca pedagogica e educazione educativa. Roma: Armando Editore.

EmplerTommaso (20 I7). ICT per il Cultural Heritage. Rappresentare, Comunicare, Divulgare. Roma: DEI - Tipografia Genio Civile. Gregory Richard L. ( 1966). Occhio e cervello. La psicologia del vedere. Milano: II Saggiatore.

Hollins Mark (1989). Understanding blindness: an integrative approach. Hillsdale (NJ): Lawrence Erbaum Associates.

Grassini Aldo (20 I5). Per un'estetica della tattilità. Ma esistono davvero le arti visive? Roma: Armando editore.

Hatwell Yvette (2006). II tatto e l'accesso manuale ai beni culturali. In Museo Tattile Statale di Ancona (a cura di). Atti del convegno L'arte a portata di mano. Verso una pedagogia di accesso ai beni culturali senza barriere. Portonovo di Ancona, 21 -23 ottobre 2004. Roma: Armando Editore.

Hooper-Greenhill Eilean (1994). The education role of the museum. London: Routledge.

Martini Berta (2016). Dispositivi ICT e musei. Efficacia formativa dell'esperienza di fruizione. In Martini Berta. II Museo Sensibile. Le tecnologie ICT al servizio della trasmissione della conoscenza. Milano: Franco Angeli.

Museo Tattile Statale di Ancona (a cura di). (2006). L'arte a portata di mano. Verso una pedagogia di accesso ai beni culturali senza barriere. Roma: Armando Editore.

Panciroli Chiara (2016). Le professionalità educative tra scuola e musei. Milano: Guerini.

Secchi Loretta (2004). L'educazione estetica per l'integrazione. Roma: Carrocci Faber.

Sennett Richard (2008). L'uomo artigiano. Milano: Feltrinelli.

Author

Andrea Marraffa, Università degli Studi Mediterranea di Reggio Calabria, andreamarraffa89@yahoo.it

To cite this chapter. Marraffa Andrea (2020). Das Triadisches Ballett reloaded: l'opera di Schlemmer al servizio di nuove connessioni spaziali e didattiche/Das Triadisches Ballett reloaded: Schlemmer's total pièce at the service of new spatial and didactic connections In Arena A., Arena M., Brandolino R.G., Colistra D., Ginex G., Mediati D., Nucifora S., Raffa P. (a cura di). Connettere. Un disegno per annodare e tessere. Atti del $42^{\circ}$ Convegno Internazionale dei Docenti delle Discipline della Rappresentazione/Connecting. Drawing for weaving relationships. Proceedings of the 42th International Conference of Representation Disciplines Teachers. Milano: FrancoAngeli, pp. 626-643. 